\title{
VETERANS AS A SOCIAL MOVEMENT: THE AMERICAN LEGION, THE FIRST HOOVER COMMISSION, AND THE MAKING OF THE AMERICAN WELFARE STATE
}

\section{Olivier Burtin \\ Ludwig Maximilian University of Munich}

N.B.: This is a postprint manuscript accepted for publication in Social Science History. The manuscript will undergo copyediting, typesetting, and review of resulting proof before it is published in its final form. Please see here for the final version:

https://www.cambridge.org/core/journals/social-science-history/article/veterans-as-a-socialmovement-the-american-legion-the-first-hoover-commission-and-the-making-of-the-americanwelfare-state/7200E05A716153DC7A0557801B867743

Please cite as:

Olivier Burtin, "Veterans as a Social Movement: The American Legion, the First Hoover Commission, and the Making of the American Welfare State," Social Science History (Spring 2020 . 


\section{Abstract:}

This article challenges the conventional view of veterans' politics in the United States as an "iron triangle" or a "subgovernment," terms which connote a low-profile field dominated by a small number of elite actors operating consensually behind closed doors. It shows instead that veterans' affairs were at the center of a heated national debate to which both grassroots activists and national leaders contributed as part of a larger social movement, as demonstrated by the controversy over the First Hoover Commission. Created by Congress in 1947 to find ways to make the executive branch more efficient, the Commission's proposals to reform veterans' affairs were all defeated by the counter-campaign of the largest and most influential veterans' group of the era, the American Legion. Former soldiers were not alone (they benefited from the assistance of key state actors such as the head of the Veterans Administration or of the House Committee on Veterans' Affairs) but their mobilization proved decisive. This episode shows that even veterans of World War II, traditionally seen as the most deserving cohort of former soldiers in U.S. history (the "Greatest Generation"), had to organize to defend their benefits against attacks. The privileged position of veterans in the U.S. welfare state is therefore less the result of their exalted cultural status (as is often presumed) than of their ability to mobilize politically and to override the preferences of significant numbers of public and private actors-just like any other group making claims on the state.

\section{Acknowledgments:}

For their suggestions and feedback, the author would like to thank Jessica Adler, Lieke Asma, Kevin Kruse, Paul Miles, Julian Zelizer, and the anonymous reviewer for the SSH. This project has received funding from the Hoover and Truman Presidential Libraries as well as from the European Union's Framework Programme for Research and Innovation Horizon 2020 (20142020) under the Marie Skłodowska-Curie Grant Agreement No. 754388, and from LMU Munich's Institutional Strategy LMUexcellent within the framework of the German Excellence Initiative (No. ZUK22). 
Most political scientists consider veterans' affairs in the United States to be one of the few policy fields still ruled by a tight-knit "subgovernment" or "iron triangle." Both these terms designate a small, stable, and consensual circle of elite actors whose deliberations produce self-serving outcomes and escape public accountability. Such static models stand in sharp contrast with those applied to higher-profile policy areas like immigration or healthcare, which after the "advocacy explosion" of the 1960s are seen to have transformed into larger and more fluid "issue networks" of experts motivated primarily by ideology and frequently clashing with each other in public (Berry and Wilcox 2018; Heclo 1978). Some scholars have challenged this view (Moore 2015), but the consensus remains that veterans' affairs are a low-profile field dominated by a small number of veterans' groups, congressional committees, and federal bureaucrats taking all the key decisions behind the scenes in Washington, D.C. (e.g. Thurber 1991: 327; Weissert and Weissert 2012: 152). Given the lack of historical background that characterizes much of the political science literature on interest groups (Strolovitch and Tichenor 2016), it is perhaps not surprising that this view has never been systematically demonstrated.

If we turn instead to the scholarship on veterans' affairs produced by historians of the twentieth-century United States, we find a very different picture. As scholars of this period have shown, the field not only included a wide range of actors but was also as much riven by bitter disputes over race, gender, class, generation, and disability as any other (Adler 2017; Boulton 2014; Frydl 2009; Kinder 2015; Keene 2001; Linker 2011; Ortiz 2010, 2012; Pash 2012; Saxe 2007). For the most part, however, historians have not built on their descriptive accounts to propose an alternative framework. Few, if any, have embraced the view of veterans' affairs put forward by specialists of other countries — such as France, Soviet Russia, and Germany — who have frequently characterized veterans' activity as a genuine "movement" (Edele 2008; Prost 1992; Whalen 1984). While it is always difficult to explain an absence, it seems fair to suggest that the reason why scholars of the United States have proved reluctant to adopt this concept is that to do so would implicitly contradict the still-pervasive view that American veterans have always enjoyed a "heralded status" in the country's political culture (Teigen 2018: 27). For to say that a group formed a movement to make claims on the state is to imply that it faced at least some resistanceor there would have been no need to organize.

Bridging the gap between political science and history, this article argues that a more productive way of understanding veterans' advocacy in the United States is to see it as part of a social movement rather than as the product of a "subgovernment" or "iron triangle." Far from being a low-profile field dominated by a static set of actors who generally agreed with each other, this policy area has long been at the center of a heated national debate to which not only elite actors but also ordinary citizens have contributed. According to Charles Tilly and Sidney Tarrow, a social movement denotes "a sustained campaign of claim-making, using repeated performances that advertise the claim, based on organizations, networks, traditions, and solidarities that sustain these activities." Like any other movement, veterans engaged in "repeated public displays of worthiness, unity, numbers, and commitment": not only did they frequently hold parades, but they often wore a distinctive uniform, had their own set of rituals, and maintained entry barriers. The core "collective frame" of the movement was the ideal of martial citizenship, according to which veterans are a select group of citizens entitled by virtue of their military service to receive special treatment from the state (Tilly and Tarrow 2015: 11).

Some readers may find that the term "social movement," which has typically been used to refer to the activities of marginalized and outsider groups, is inappropriate to describe a campaign whose base (veterans) consisted predominantly of white men with relatively easy access to 
policymakers. There was clearly a difference between former soldiers on the one hand and other kinds of social movements led by labor unions or civil rights groups on the other. The more privileged status of the former meant that they typically (but not exclusively) worked within the political system instead of using more confrontational methods. ${ }^{1}$ Veterans relied on what political scientist Eldon Eisenach has called "parastate" organizations (Eisenach 1994): private associations that served as intermediaries between the state and individual citizens, such as the American Legion, the Veterans of Foreign Wars, and the Disabled American Veterans. They also had powerful allies within the state, such as the Director of the Veterans Administration Frank T. Hines or the Chairman of the House Committee on Veterans' Affairs John E. Rankin. Still, because veterans' groups were not only closely connected to each other but also relied heavily on the active participation of their rank-and-file, it is fair to see them not just as a collection of interest groups but as the leaders of a larger social movement.

A proper demonstration of this thesis would require a discussion of the entire span of U.S. history, but such a comprehensive survey is beyond the scope of this article. Instead, I provide here an in-depth case study of one veterans' group (the American Legion) during the time period where we would perhaps least expect to find veteran organizing: the post-World War II years. According to conventional wisdom, veterans from this war were the "Greatest Generation," a cohort of heroes who upon their return home were rewarded by a grateful population with such generous benefits as the "G.I. Bill of Rights" of 1944 (Brokaw 1998). Yet this article shows that even the generation seen as the most deserving of all had to fight to defend its benefits. Readers may find confirmation that veterans' politics in other periods was also the topic of heated debate nationwide with widespread grassroots involvement in the rich scholarship covering the debates over Revolutionary War pensions (Jensen 2003; Resch 1999), benefits for Civil War veterans (Marten 2011; Shaffer 2004; Skocpol 1992), the Bonus Army in the interwar period (Dickson and Allen 2004), and the effects of Agent Orange after the Vietnam War (Nicosia 2001; Scott 2004), to cite only a few examples.

More precisely, the article explores the case of the Commission on Organization of the Executive Branch of Government, better known as the First Hoover Commission (Arnold 1976; Grisinger 2012: 153-94; Moe 1982; Pemberton 1986; Walch and Miller 1992: 129-79). Created by Congress in 1947 to find ways to streamline the executive branch, this blue-ribbon group was unusually influential. Under the chairmanship of former President Herbert Hoover, it not only produced an exhaustive study of governmental organization but also spearheaded a bipartisan movement in favor of administrative reform with support from liberals and conservatives alike. Its campaign proved remarkably successful: over 70 percent of its recommendations were eventually implemented, resulting in total estimated savings of between $\$ 5$ and $\$ 7$ billion (House Committee on Government Operations 1963: 6-7). More specifically, the Commission represented the first attempt to downsize the massive structure of veterans' benefits that had emerged from World War II. By 1949, these programs accounted for nearly one-third of all public expenditures on social welfare, more than any item of federal spending other than the military (Carter et al. 2006: tables Ed 297-310, Bf188-195). The Commission threatened to radically undermine this separate welfare state by integrating veterans' hospitals into a unified federal medical agency and by diminishing the advantages enjoyed by former soldiers in civil service.

Despite its otherwise positive record, none of the major recommendations of the Commission regarding veterans' affairs were eventually translated into law. The only scholar to

${ }^{1}$ Some veterans' groups were more radical than others. After World War I, for instance, the World War Veterans embraced explicitly Marxist beliefs, see (Pencak 1989, 51). 
have studied this episode portrayed it as the almost predictable result of a lopsided battle against entrenched political and bureaucratic interests (Frydl 2009: 179-85). This article sheds light on a lesser-known but equally important dimension of this story: the counter-mobilization effort led by the champion of the veterans' movement, the American Legion (Pencak 1989). Legion leaders had pragmatic as well as ideological objections to Hoover's proposals: not only did they question the idea that taking veterans' programs away from the Veterans Administration (VA) would make them more efficient, but they also pushed back against what they saw as an attempt to undermine the status of former soldiers as an especially deserving category of the population. Using raw emotional appeals to galvanize their rank-and-file members across the country, they channeled their energy into a well-orchestrated national campaign to put pressure on lawmakers in Washington. Their hard-hitting strategy provoked a backlash in the press as well as among some moderate members of Congress, but it succeeded in swaying most policymakers. When the First Hoover Commission disbanded in 1952, veterans' welfare state remained largely intact.

To see veterans' advocacy as a social movement changes our view of American politics in two ways. First, it means that veterans' position as one of the several privileged groups in the upper half of the "two-track" U.S. welfare state (Katz 1989; Gordon 1992) was not the inevitable result of a longstanding cultural tradition of rewarding former soldiers for their sacrifices, but rather the product of their own political mobilization. Like many other groups, veterans have been characterized as unworthy of state assistance - much more so than we now remember. They had to fight to receive their benefits; there was never a time when their status was secure. Second, this new framework seeks to encourage comparisons across time and space. By stressing how martial citizenship in the United States was contested and unstable, it shows how much the country has in common with other nations where veterans had to organize to defend their shared interests, thus allowing scholars to move beyond a still dominant exceptionalist perspective. This article thus represents an attempt to include the United States in the small but expanding scholarship on comparative veterans' politics (Alcalde and Seixas 2018; Crotty and Edele 2013; Eichenberg and Newman 2013; Dandeker et al. 2006; Danilova 2010).

The article begins by laying out the context in which the First Hoover Commission was created and made its proposals to reform veterans' programs. It then describes the groups and arguments deployed on either side of the debate. Finally, it closes with an account of how this dispute unfolded, from the first skirmish in 1949 to the eventual victory of the veterans' movement in 1952.

\section{A. The First Hoover Commission and Veterans' Welfare State}

In the two decades that followed the onset of the Great Depression in 1929, the U.S. state experienced tremendous growth. The level of annual federal expenditures and debt per capita grew more than tenfold, while the number of public employees nearly quadrupled (Carter et al. 2006: tables Ed26-47, Ea650-661, Ea636-643, Ea894-903). Owing in part to President Franklin Delano Roosevelt's lack of interest for administrative matters, this expansion was as rapid as it was disorderly. By 1949, the executive branch counted between 74 and 89 different staff offices, departments, regulatory agencies, boards, and commissions, often with overlapping functions (House Committee on Expenditures in the Executive Departments 1949a: 47-50). Due to the absence of a central records facility, for instance, more than seventy government divisions ran their own storage facilities in the capital (Walch and Miller 1992: 18). Roosevelt's successor Harry Truman tried to remedy these shortcomings in his first two years in office, but his efforts were 
stymied by the conservative coalition of Republicans and Southern Democrats in Congress. Bent on rolling back the New Deal, they adamantly opposed any attempt to streamline its structure (Pemberton 1979: 21-78).

It was precisely to dismantle Roosevelt's legacy that congressional conservatives created a new blue-ribbon commission in July 1947. Acting on the then-widespread assumption that Truman would lose the upcoming presidential election, they hoped that it would produce a blueprint to help the next Republican administration scale back government. Though the committee was nominally bipartisan and included a few staunch liberals such as future Secretary of State Dean Acheson and former assistant to Roosevelt James Rowe, the appointment as chairman of Herbert Hoover made it abundantly clear that its goal was to liquidate the New Deal state. The ex-President turned champion of the GOP's right wing largely controlled the group's early work (Pemberton 1986: 520). His ambitions were frustrated, however, when Truman won re-election against all odds in November 1948. Facing the prospect of another Democratic administration and Congress, Hoover struck a deal, agreeing that his Commission would no longer challenge some of the basic functions of government but instead find ways to make them more efficient. Truman thus seized the opportunity to claim the mantle of bipartisanship for his own reorganization plans, turning a Commission initially designed to do away with his legacy into an instrument to solidify it (Pemberton 1986: 518-519).

The Commission eventually submitted nineteen reports over the first half of 1949, each covering a specific aspect of the executive branch. Collectively, they were known as the Hoover Report ("Summary of Reports" 1949). They sought to streamline the confused tangle of agencies and departments by following three basic management principles. First, they called for the establishment of a centralized and continuous chain of command flowing from the President down to the local level, so that ultimate responsibility and accountability always lay at the top. Second, they tried to reorganize executive agencies in order to eliminate any functional overlap, with the goal of consolidating them into one-third of their current number. Lastly, they aimed to expand the staff assigned to the President and department heads in order to improve the supervision of subordinate agencies (House Committee on Expenditures in the Executive Departments 1949a: 18). From these broad principles stemmed no less than 273 specific recommendations, some narrowly technical and others more substantial. Among the most important were the unification of the military under a civilian Secretary of Defense, the creation of a new General Services Administration to furnish supply, records, and building maintenance to all executive agencies, and the decentralization of personnel recruitment and management away from the Civil Service Commission to individual agencies.

Veterans' affairs loomed large in the Hoover Report. This was hardly surprising, since the range of benefits available to former soldiers had expanded tremendously during World War II. Not only did the war cause the veteran population to grow from 4 million in 1940 to 19 million in 1949, but the passage of the 1944 "G.I. Bill" created a set of brand-new benefits in the realms of education, business, home, and farm loan guaranties, and unemployment compensation. With 129 hospitals and an average daily patient load of 107,000, the VA hospital system was now the largest in the nation. The agency handled about 7.7 million life insurance policies for a total value of over $\$ 155$ billion. In terms of employees, it was the third largest government entity behind the military and the Post Office (Annual Report 1941: 1-7; Annual Report 1950: 1-4, 73-74). As one Canadian expert put it, the VA had in just a few years come to play the role of "bank, benefactor, hospital, custodian, life insurance company, educational endowment, guardian of orphans, medical adviser, vocational counselor, welfare agency, protective and benevolent association, property appraiser, 
loan guarantor and broker, compensation board, old age shelter and burial society, to nineteen million adults who under its auspices go to school, seek and find jobs, purchase farms and businesses, buy houses, are ill in veterans' hospitals, and buried in national cemeteries" (England 1950: 94-95).

Not all this growth was painless. Despite the repeated assurances of its Administrator Frank T. Hines, the VA proved woefully unprepared to handle the postwar demobilization ("Disabled Veterans Will Receive Care" New York Times, 1944; "Plans Are Already Under Way" The Christian Science Monitor, 1944). In January 1945, damning exposés of the situation began to appear with increasing frequency in the press. In the New York newspaper $P M$, Albert Deutsch called the VA a "vast dehumanized bureaucracy, enmeshed in mountains of red tape, ingrown with entrenched mediocrity, undemocratically operated under autocratic control centered in Washington, prescribing medieval medicine to its sick and disabled wards, highly susceptible to political pressures, rigidly resistant to proposed reforms" (quoted in Bradley and Blair 1983: 441). Yielding to public pressure, Truman replaced Hines with four-star Army General Omar N. Bradley, known for his leadership skills as Eisenhower's right hand during the war. Over the course of his next two years in office, Bradley implemented a series of reforms that profoundly overhauled the agency, such as the creation of a new Department of Medicine and Surgery (Bradley and Blair 1983: 446-462; Kammerer 1948). But even he was unable to solve all the VA's problems before his planned departure in December 1947. The agency's reputation remained tarnished for years to come, creating a window of opportunity for its critics. As one of Hoover's lieutenants remarked a few years later, "[t]here is no more vulnerable agency in government today than the VA" (Coates to Smith 1951).

Aware of this unique opening for reform, the Hoover Commission made two sets of recommendations concerning veterans' benefits. The first had to do with its larger emphasis on functional re-organization. Following this principle, the Commission called for the consolidation of most large-scale federal medical activities - military and VA hospitals as well the Public Health Service - into a new United Medical Administration (UMA) (House Committee on Expenditures in the Executive Departments 1949b: 2-3). This proposal would have taken away from the VA not only its largest division (Annual Report 1949: table 100) but also its most prestigious. Indeed, the Department of Medicine and Surgery had been the only unqualified success of Bradley's tenure. Thanks to the alliance forged by his Medical Director Paul R. Hawley with medical schools, observers could claim by 1947 that veterans' healthcare had become "second to none!" (Miller and Monahan 1947). In addition, the Commission recommended the transfer of the G.I. Bill housing loan guaranty program from the VA to the Housing and Home Finance Agency and of hospital construction to the Department of the Interior, as well as the incorporation of all life insurance operations into a semi-autonomous corporation within the VA. The management structure of the agency was to be streamlined too, so as to give the Administrator more control (Senate Committee on Expenditures in the Executive Departments 1949; House, Committee on Veterans' Affairs 1949c). In a nutshell, the VA would lose its core functions and undergo a structural overhaul.

The second category of recommendations reflected the Commission's attempt to strengthen the authority of heads of departments and agencies and to improve the quality of their administrative staff. Since at least the Civil War, veterans had enjoyed a range of advantages in civil service. Not only were they granted five additional points on entrance exams (ten with a service-connected disability), but certain positions such as elevator operator and custodian were reserved for them. Minimum educational, height, age, and weight requirements were waived. They 
were also the last to be fired and the first to be re-employed (Roher 1946). These benefits proved highly popular: in March 1951, nearly 59 percent of all civilian employees of the federal government were veterans (Proceedings of the $33^{\text {rd }}$ National Convention 1952: 173). For the Hoover Commission, however, such rules made it harder to hire and promote the best candidates and to fire incompetent workers, and therefore prevented the establishment of a truly meritocratic system. To remedy this situation, it called for the Civil Service Commission to relinquish some of its control over the recruiting and examining process to the heads of departments and agencies. In addition, it recommended the end of the absolute preference enjoyed by veterans in reduction of force procedures. Finally, instead of giving veterans a straightforward point bonus, all applicants for a given position were to be grouped into categories such as "outstanding," "well-qualified," "qualified," and "unqualified," and veterans were to be considered ahead of non-veterans only within those categories. ${ }^{2}$ The Commission also recommended carrying out a nation-wide recruiting campaign over the next few years to help place veterans in government positions, but this was clearly an attempt to sweeten the pill of what amounted, overall, to a blistering attack on the principle of veterans' preference in civil service (House Committee on Expenditures in the Executive Departments 1949b: recommendations no. 2, 7-9, 23).

\section{B. The Coalition for Administrative Reform and the Veterans' Movement}

The Hoover Report was only the latest in a long series of attempts to reform veterans' benefits dating back to Progressives' failed efforts to revamp the Civil War pension system in the latenineteenth and early-twentieth century. The creation of the Veterans' Bureau in 1921 and its successor the VA nine years later had been motivated precisely by an impulse to achieve efficiency in government by placing all services for veterans under the charge of a single federal agency. Roosevelt was also seeking economy when he cut $\$ 460$ million in veterans' programs with the Economy Act of 1933, but most of its provisions were quickly rolled back by Congress (Ortiz 2010; Stevens 2012). FDR later created the Brownlow Committee, which he tasked-exactly like the Hoover Commission several years later-with finding ways to reorganize the executive branch. The Committee suggested that the VA as a whole should be placed under the authority of a new Department of Welfare, but the proposal was abandoned when it faced fierce pushback (Polenberg 1966: 80-81). After the temporary halt of the war, Hoover was the first to take up the torch of these reform efforts. Having presided over General Douglas MacArthur's brutal removal of the Bonus Marchers from the federal capital in 1932, he knew first-hand how explosive veterans' issues could be.

A seasoned statesman, Hoover anticipated that his proposals would not sail effortlessly through Congress. After submitting its last report in June 1949, the normal course for his Commission would have been to disband. Instead, the ex-President took the additional step of creating the Citizens' Committee for the Hoover Report (CCHR). The mission of this group was to conduct a national publicity campaign with the goal of "keeping the ideas and recommendations of the Commission alive, and of encouraging [their] adoption" ("A Program" 1948). Hoover maintained close ties with the committee but delegated its direction to the president of Temple University and former vice-president of Time magazine Robert L. Johnson. His Director of Public Relations was Charles B. Coates, an executive at General Foods (Grisinger 2012: 163), and his

${ }^{2}$ Disabled veterans were to be considered ahead of everyone else, but only for certain low-level positions. 
Research Director Robert L. L. McCormick, a banker and Harvard Business School graduate (McCormick to Weymouth 1950; White 1952).

With \$390,000 budgeted for the first year, the CCHR soon had affiliates in thirty-seven states. In order to mobilize support for specific pieces of legislation, it endorsed television shows, published pamphlets and newsletters such as Washington Watchdog or the Committee Report, and provided favorable materials to thousands of independent newspapers as well as hundreds of companies nationwide (Coates 1949; Pemberton 1979: 110). The CCHR also launched the "Cracker Barrel Caravan" in May 1950, a road show whose centerpiece was a red-white-and-blue trailer carrying a 30-foot long imitation of an old-fashioned country store fitted out with an actual cracker barrel serving as a rostrum for speakers and actors. Over the course of three months, the Caravan brought government reorganization alive at every stop, distributing 90,000 pamphlets and signing up thousands of new members ("Impact!" n.d.). Arguably, never before had the rather dry subject of government reorganization been so widely publicized.

Their effort was both broadly popular and remarkably bipartisan. As political scientists Charles Aikin and Louis W. Koenig wrote in 1949, "[i]t has become something of a mode to favor the Hoover reports, just as one opposes sin" (Aikin and Koenig 1949: 933). At the first National Reorganization Conference organized by the CCHR that year, Truman sent a message of support and the list of speakers included Democratic Governor of Illinois Adlai E. Stevenson, Secretary of Labor Maurice J. Tobin, Secretary of Defense Louis Johnson, Lewis Hines of the A.F.L. and Stanley Ruttenberg of the C.I.O., and Republican Senator from Wisconsin Joseph McCarthy (Knowless 1949; "National Reorganization Conference Agenda" n.d.). Major press organs also expressed their approval. The conservative Chicago Tribune, for instance, praised the Commission's "great intelligence and drive" ("4 Billions Not Saved" 1950). The Washington Post called the report "the most thorough job in history in a study of this Government" and the Wall Street Journal praised its "fine service in showing us what a cancer bureaucracy has become" (quoted in Grisinger 2012: 181). In the New York Times, James MacGregor Burns claimed that the Commission's "excursion into the Dark Continent of the national bureaucracy" had shown that "our super-Government... has become a fixed part of the "American way of life"" (Burns 1949). Americans in general also approved: in September 1950, the White House mailroom counted no less than 45,600 newspaper poll clippings and petitions in support of the Commission (Clark 1950).

The same political scientists who compared endorsing the reports to opposing sin, however, also noted that "just as many of us deplore sins we have never experienced, so, unfortunately, many who exalt the Hoover reports actually have never read them" (Aikin and Koenig 1949: 933). Indeed, a March 1950 Gallup poll reported that 69 percent of respondents either did not know about the reports or did not understand them well. The survey also showed a clear class divide, with the percentage of respondents informed about the report ranging from 65 percent among the college-educated to no more than 18 percent among those who had graduated only from grade school (Gallup 1950).

Still, the proposals of the Commission elicited broad support among the elite segment of the population, which agreed on the need to overhaul veterans' programs. Think tanks such as the Public Affairs Institute, for instance, welcomed as "both sound and obvious" the transfer of VA hospitals to an integrated medical administration, on the basis that "veterans are first and foremost citizens and...their needs should be considered in the same way as the needs of other human beings" (Public Affairs Institute 1949). Frances T. Cahn of the Brookings Institution likewise called for the revision of veterans' preference in civil service, comparing the advantages it granted 
this group to "a handful of sand in a gear box," which "fouled and stalled the whole delicate machinery that had been set up to find, measure, and secure merit" (Cahn 1949). Major newspapers agreed. The Washington Post declared its support for eliminating veterans' preference and agreed with the New York Times that the Hoover Commission was "not going nearly far enough" ("Veterans' Report" New York Times 1950; "Congress and Legion" The Washington Post 1950; "Veterans' Preference" The Washington Post 1949). Writing in the former, columnists Ysabel and Robert Rennie saw the Commission as a chance to "reconsider most seriously that bright political line dividing the veteran from the citizen." "Functionally," they argued, the centralization of so many different jobs into one agency was "absurd." The recommendations of the Hoover Commission to put these functions back "where they belong" made sense, for in the end veterans should be treated like any other citizens (Rennie and Rennie, 1950).

A bipartisan coalition soon arose to support these proposals. Liberals joined because they saw the growing size and cost of veterans' benefits as a threat to more universal welfare programs. For instance, Truman argued in his 1950 Budget Message that instead of providing special benefits to veterans without service-connected disabilities "[o]ur objective should be to make our social security system more comprehensive in coverage and more adequate, so that it will provide the basic protection needed by all citizens" (Truman 1950: 68). The liberal veterans' group American Veterans' Committee, led by the owner of the New Republic Michael Straight, also endorsed the Hoover Report (“American Veterans," New York Times 1950). As for conservatives, they resented the dramatic expansion of the federal government in general and pushed for large spending cuts. Prominent right-wing anti-communist activist George Sokolsky, for instance, argued that generous veterans' benefits entailed a larger bite in Americans' purchasing power. "In the end," he wrote, veterans "will pay more in taxes, in devalued dollars, in high prices, than they get in benefits." "Profligacy is a misery no matter who practices it," he added, "and a profligate government becomes a menace to its citizens" (Sokolsky 1949). Business-friendly groups such as the Junior Chamber of Commerce and the U.S. Chamber of Commerce were among the most fervent allies of the CCHR (McCormick to Hoover, October 1950). Despite its uneven support among different categories of the population, this ad hoc coalition it was still a powerful foe.

Another clear sign that the Commission's agenda posed a serious threat was the alarmed reaction of the American Legion, whose National Commander Perry Brown called the Hoover Report a "real crisis for all war veterans" (Brown 1949: 14). Coming from a group that stood at the peak of its power in the postwar period, such comments were not insignificant. In these years, the Legion counted roughly twice as many members as the second largest veterans' organization, thanks to the recent addition of about two million World War II veterans to its base of nearly one million former soldiers of the Great War. ${ }^{3}$ These numbers spoke to the group's considerable influence: according to political scientist Dayton McKean, the Legion was "commonly regarded by Washington newspapermen as the most powerful pressure group of any sort" (McKean 1949: 510). Likewise, a Roper survey conducted in the early 1950s found that the Legion was the civic group to which Americans turned most often for an opinion about a political candidate, ahead of churches and unions (Roper 1952).

Like many other veterans' groups, the Legion had a federalist structure: a national body presided over relatively autonomous state-level "Departments," each of them with authority over its own local Districts and Posts. At the top of the organization was the National Commander, elected every year to manage the group's day-to-day business along with a small number of

${ }^{3}$ In October 1946, the membership of the Veterans of Foreign Wars stood at 1.5 million, see (Mason, Jr. 1999, 115). 
permanent national committees and officials. With about 15,000 local Posts after World War II, the Legion was present in nearly every community across the land and could therefore exert direct influence over most of the nation's representatives in Congress. The fact that Legionnaires were an overwhelmingly white, male, and middle- and upper-class group also helped. Though their leaders liked to claim that their organization was "a representative cross-section of the population," in reality it was composed largely of small businessmen, civil servants, and professionals: men who formed the backbone of their communities and who had the time and resources to get involved in civic activities. Nowhere was the Legion more influential than in small towns and rural areas, even though it also represented a significant force in many large cities (Pencak 1989: 78-105).

In addition to its federalist structure, the Legion also adopted many features that were typical of a fraternal order (Carnes 1989; Clawson 1989). All members were expected to wear a dark blue, military-style uniform on public occasions, with a cap whose color reflected their position in the group's hierarchy (blue for local, white for state, red for national). The leadership issued a manual of ceremonies, which explained in detail the elaborate rituals to be performed for events such as the initiation of new members or the opening of a Post meeting. In addition, the Legion had its own women's Auxiliary, open to all female relatives of Legionnaires. With 800,000 members (Gray and Bernstein 1948: 99), the Auxiliary not only focused on charitable and community work - activities traditionally seen as female — but also often played an outsize role in Legion lobbying campaigns (Pencak 1989: 296-301; Zeller 1937: 204-9). Locally, the Legion sponsored a wide range of social activities that ranged from youth projects such as Junior Baseball or Boys State to civic and charity programs like disaster relief, auto safety, or marksmanship training. In Illinois, for instance, local Posts helped bail veterans out of jail, provided firing squads at funerals, sponsored local talent shows, and helped raise funds for youth recreational facilities (Littlewood 2004: 32-33). In all these ways, the Legion was representative of the veterans' movement as a whole, whose deep roots in local communities were inseparable from its influence at the national level.

The Hoover Report represented a threat to this movement - and to the Legion - for two reasons. On a first level, Legionnaires disagreed that its proposals would produce greater economy and efficiency. Dispersing veterans' programs into several agencies, they argued, would not only require duplicating veterans' records but also increasing taxes to support the creation of new bureaus to do a job already performed by others. As a suggested script for local Legion speakers put it, the Commission's proposals for the VA amounted to telling General Motors that "You may retain your administrative functions, but you will have to divorce yourself from the other operations of your corporation. Ford will take over your production. Engineering will go to Studebaker. Your distribution will be conducted by Chrysler. And your sales can be handled by Kaiser-Fraser" (National Public Relations Division n.d.). Legionnaires argued that the proposals would only result in more confusion and a less efficient service for veterans, who would not be able to rely on a "one-stop" agency anymore (which, they noted ironically, was precisely why Hoover had supported the creation of the VA back in 1930 when he was President). "No longer could the veteran go to one agency and inquire about his disability claim, check up on his chance to get vocational training, make application for hospitalization if he were ill, inquire about a G. I. loan, or if called in for a physical examination, do it all in one place [sic]. He conceivably might have to visit four or five different Federal agencies" ("What Would Happen" n.d.).

But the clash between the Legion and the Hoover Commission was also about conflicting visions of citizenship. For the Legion, veterans formed a privileged class of citizens by virtue of their military service and any benefits they consequently received were the product of a moral 
contract between them and the Government, "a sacred obligation of the nation" (National Public Relations Division n.d.). It was above all this ideal of martial citizenship that the group sought to defend. They argued that the recommendations of the Hoover Report to take core functions away from the VA and place them under the authority of a non-veteran-specific agency would "divorce all veterans from their identity as veterans" and thus "tear down what [the Legion] has worked a lifetime to build" ("McCurdy Denounces Economy," American Legion Magazine 1950; "Legion Declares Private War," The Badger Legionnaire 1950). "It is particularly alarming," wrote a top Legion official, "to have the veterans' benefit programs classified as welfare programs. We resist that idea whenever it is possible to do so...The American Legion has consistently held to the position that the cost of caring for the disabled veteran is as much a part of the cost of war as are the cash moneys laid on the barrel head to pay for the ships and guns and tanks and planes...such Federal veterans benefits are a direct cost of war. They have no relation to the Oscar Ewing type of welfare state cost" (Ewing was the man in charge of the Federal Security Agency, which was responsible for some of the most emblematic New Deal welfare programs like Social Security) (Kraabel to Falcone 1952). The Hoover Report, in short, risked undermining the special status of veterans' programs as earned rights instead of "welfare," a term understood to designate charity for the poor, with negative connotations of feminine dependency.

While the Legion was by far the largest veterans' group, it was not alone in this fight. All the other major actors of the veterans' movement - from the Veterans of Foreign Wars (VFW) to the American Veterans of World War II (AMVETS) and the Disabled American Veterans (DAV) - rallied against the proposals of the Commission ("Battle Developing over Veteran Unit," New York Times 1950). They were joined by VA Administrator Carl R. Gray, Jr., who saw the Report as a threat to his own administrative turf. In a letter to Congress, he used a language similar to the Legion's to argue that nearly all of Hoover's recommendations were "in basic conflict with the traditional policy of the Government to accord to veterans as a class, special consideration through one agency responsible for administering the various benefit programs" (House, Committee on Veterans' Affairs 1949a: 4). The key gatekeeper for all veterans' legislation in Congress, the House Committee on Veterans' Affairs, was also in friendly hands. The Legion had been instrumental in its creation in 1924-following the same logic as for the VA, that veterans' policies ought to be separate from other matters - and maintained close ties with its chairman, John E. Rankin (Ortiz 2010: 23). A Southern Democrat from Mississippi, Rankin was known as the "foremost defender in Congress of white supremacy and one of the most vicious of the [anticommunist] witch hunters" ("Exit Mr. Rankin," The Washington Post 1952). He was also a staunch ally of veterans' groups (Ross 1969: 24-25).

Though veterans enjoyed the support of such key figures, their standing with public opinion was far from secure. In February 1950, a Gallup poll asked whether Congress should follow the Hoover Commission's plan to "[split] up major functions... of the VA among other government agencies" or veterans' organizations' claim that "it would be neither efficient nor economical." While a plurality of respondents (44 percent) sided with veterans, those who agreed with the Commission were not far behind (34 percent) and could potentially become a majority if more of the rest took a stand (Gallup Organization 1950). With the lines clearly drawn between two diametrically opposed visions of veterans' role in society, both with support not only in Washington, D.C., but across the country, the battle over the Hoover Report could begin.

\section{Ideas in Practice: The Fight over Martial Citizenship}


Though the positions of the Legion and the Hoover Commission were at loggerheads, their conflict did not immediately burst into the open. Hoping to avert a head-on conflict, CCHR officials organized a few top-level meetings with their Legion counterparts. But while Coates held out hope of a compromise, the Legion was gearing itself for an all-out attack (Coates to Ely 1950). In early December 1949, while negotiations were still running, the new National Commander George N. Craig invited all Legion Departments to send delegates to a national meeting the next month in Indianapolis, with the explicit goal "to discuss and formulate plans to defeat the Hoover Commission Report and the legislation that has been introduced as result of such recommendations" (Craig 1949; "Suggest Agenda" 1950). Later, Craig emphasized that defeating the Hoover Report would be "the NUMBER ONE legislative problem" of the Legion for the upcoming year (Letter from George Craig, 1950).

When the meeting opened in January 1950, Legion officials outlined "Operation Survival," a nationwide public relations campaign that delegates were to launch upon returning to their Departments (McGinnis n.d.). Similar to the CCHR's own approach, the Legion's operation sought to sway public opinion and lobby Congress in preparation of the group's National Rehabilitation Conference the next month in D.C., when Departments would meet with their Congressional representatives ("National Rehabilitation Conference" 1949). Every state delegation was given a brochure with background material, suggested editorials, a series of seven stories to be published by local newspapers, and suggested five-, ten-, and fifteen-minute talks for Legion and Auxiliary speakers ("American Legion Mobilizes," American Legion Magazine 1950). The public launch of the campaign came a week later, when the Legion testified against the Hoover Report at a highly publicized hearing of the House Committee on Veterans' Affairs ("Battle Developing over Veteran Unit," New York Times 1950). Craig later met with President Truman to discuss his objections (“Truman, Legion Head Talk," New York Times 1950).

Aware that their success depended largely on the response of their rank-and-file, Legion officials adopted an aggressive rhetoric. The bellicose tone of the Badger Legionnaire, the official monthly of the Wisconsin Department, was typical of Legion publications throughout the country. In an article headlined "Legion Declares Private War," Wisconsinites learned that Craig had sounded a "call to arms" and outlined a "mobilization plan." The material distributed at the January meeting was described elsewhere as a "full supply of ammunition" ("Pass the Ammunition!" The American Legion Magazine 1950). The Badger Legionnaire went on to claim that the Hoover Commission was responsible for a "ruthless campaign to sell the veteran down the river." The Hoover Report was "another knife in the backs" of veterans. "The time for silk gloves is past," it concluded in a rhetorical flourish, "Now is the time to take off the gloves... use brass knucks if necessary... and keep swinging until we have kept faith with our less fortunate veterans!" ("Time for Action," The Badger Legionnaire 1950). Not to be outdone, the Legion's internal newsletter directly attacked Hoover himself, circulating a cartoon that portrayed him as insensitive to the plight of a disabled veteran unable to find a bed in a United Medical Administration hospital where he no longer had priority. ${ }^{4}$

This strategy provoked an immediate backlash, illustrating the limits of the public' support for the veterans' movement. As Coates later commented joyfully, the cartoon of Hoover and the warlike language of Operation Survival "brought the newspapers and Members of Congress down around [the Legion's] ears like a swarm of hornets" (Coates to Johnson 1952). At a hearing on the United Medical Administration, Craig was castigated by several Congressmen. Georgia Democrat Henderson Lanham called the Legion propaganda "very unwise" and "very unfair," while William

\footnotetext{
${ }^{4}$ The cartoon was reprinted in (“American Legion Cartoon," New York Herald Tribune 1950).
} 
L. Dawson, a liberal Democrat from Chicago, advised Craig that "sending threatening letters" would not get the desired response but "rather raises an antagonism" (United Medical Administration 1950: 35-36). The reaction of the press was even more negative. The Washington Post and the New York Times dismissed the Legion's charges as "plain tommyrot" and "the height of absurdity," while the Washington Times-Herald called the Hoover cartoon the "dirtiest kind of dirty pool" ("Congress and Legion" The Washington Post 1950; "Veterans' Report" New York Times 1950; "Play Fair, Legion,” Washington Times-Herald n.d.).

As importantly, newspapers explicitly condemned the idea that veterans deserved special status. The concept that former soldiers belonged to a separate and privileged class of citizens and that their benefits should therefore remain under the single authority of the VA, in the view of Long Island's Newsday, was a self-interested position underpinned by "the idea of perpetrating [the Legion's] own power to manipulate the VA" ("Pressure," Newsday 1950). "In the long run," the Post agreed, "the real enemy of the veteran may prove to be the leader who wants to keep him out of the main stream of American life, who wants to isolate him and make him a member not of the whole community but of a manipulable special interest group" ("Legion Blast," The Washington Post 1950). The Times also called on the Legion to stop "acting as though the veterans of this nation are and want to be a specially privileged class set apart from the rest of the population" ("Veterans' Report" New York Times 1950).

As a new session of Congress began in January 1950, four different bills embodied the recommendations of the Hoover Commission on veterans' affairs. Two of them-to reorganize the VA and to create a Veterans' Insurance Corporation - fell under the jurisdiction of Rankin's committee, who buried them without a hearing. The bill to reform federal personnel management went before the House and Senate Committees on Post Office and Civil Service. But it was the UMA that the Legion saw as the most serious threat. As Craig argued in his testimony before the House Committee on Expenditures in Executive Departments, "the medical and hospital program of the VA is the key point in that organization...Take that out of the VA, and the remaining structure is greatly weakened" (House Committee on Expenditures in the Executive Departments 1950: 15-16).

Since the UMA debate took place within the broader context of the fight over national health insurance between Truman and the powerful doctors' lobby, the American Medical Association (AMA), it is worth stepping back for a moment to understand the larger dynamics at play here (Poen 1979). In his State of the Union address in January 1949, Truman had proposed the creation of a Department of Welfare to perform the functions administered by the FSA, a move opposed by the AMA because it would have elevated to cabinet rank those government officials who were among the staunchest advocates of national health insurance, which it condemned as "socialized medicine." Southern Democrats were also against it because of Ewing's support of civil rights. As a result, the Senate voted the plan down. The Hoover Commission tried to sidestep this conflict by taking health activities away from the FSA and into the United Medical Administration, while recommending the creation of a new Department of Welfare with authority only over education and social security (Pemberton 1979: 117-20). Yet this compromise only ended up displeasing both sides. The AMA believed health activities should be incorporated into a Department of Health instead of another agency with lower status, while Ewing declared himself "unalterably opposed" to the transfer of the Public Health Service away from his agency (Senate Committee on Labor and Public Welfare, Subcommittee on Health 1950: 70; Senate Committee on Expenditures in the Executive Departments 1949: 328-331). Their hostility placed them in the same camp as the veterans' movement. 
As important as these allies of circumstance were, the real strength of the Legion lay beyond Capitol Hill. Long before the first hearings had even been held, the rank-and-file's response to Operation Survival exceeded the wildest expectations of their leadership. Within less than two weeks after the January meeting, more than half of all Legion Departments in the continental U.S. reported that they had taken action (Oakey to Kraabel 1950). In Texas, the 21 district Commanders met in Austin and agreed to poll their own Congressmen and to hold meetings in all 758 Posts in the state (Department Headquarters 1950). In Ohio, the Department Adjutant reported an "enthusiastic," "emergency state-wide meeting," "with perhaps 700 to 800 present," of which "about 70 per cent" were World War II veterans" (Deutschle to Craig 1950). In Washington state, model petitions were sent to individual Posts, veterans applying for disability claims received flyers, Department officials crisscrossed the state to give speeches, and a speaker's bureau was set up (Fuecker to Dudley 1950). A Northern California pro-Hoover group reported to the CCHR that "a vigorous attack is being made by the American Legion" in the region, adding that "we are encountering it everywhere" (McAtee to Coates 1950). In Albuquerque, New Mexico, an "overflow crowd jammed" the local high school auditorium to hear the Legion state Commander "lash out" at the Hoover Report ("State Legion Head" n.d.). Finally, in Alabama a petition with 20,000 names was sent to Washington, D.C., and local newspapers agreed to insert large anti-Hoover Report ads at no cost ("Hoover Commission Report" 1950). In addition to all this local agitation, Department representatives met with their Congressional delegations at the Legion's National Rehabilitation Conference in early February ("National Rehabilitation Conference" 1949). Clearly, rank-and-file veterans were responding enthusiastically to the Legion's message.

This combination of grassroots support and national leadership proved decisive. Though the Army Times Newsletter disapproved of the Legion's propaganda campaign, it was forced to concede barely a month after its launch that it "already can be labeled an unqualified success," adding that " $[\mathrm{m}]$ embers of Congress are jumping through Legion-held hoops like well-trained animals" (quoted in Warner 1950). Indeed, many Departments followed Nevada in reporting that their Congressional delegation was "on record squarely behind our program" ("Hoover Commission Report" 1950). By February, influential legislators on both sides of the aisle, such as former chairwoman of the House Committee on Veterans' Affairs Edith Nourse Rogers (R-Mass.) and House Majority Leader John W. McCormack (D-Mass.) had come out against the recommendations of the Hoover Report on veterans' affairs (Mundt to Craig 1950; National Legislative Commission 1950). Their statements embraced the view that veterans deserved special treatment: McCormack, for instance, condemned the transfer of functions out of the VA on the ground "that veterans rights would be trimmed" ("House Leader Says Split," American Legion Magazine 1950). In a letter to the President, both Democratic Oklahoma Senators Elmer Thomas and Robert S. Kerr expressed the position of their state's entire Congressional delegation in terms that could well have been the Legion's. "We believe," they wrote, "that in order to provide a special service for a segment of our people, a special agency must be provided for its administration...there remains uppermost in our minds the necessity for a continuous program of benefits for our war veterans above and beyond those provided for the whole of our citizenry" (Thomas and Kerr to President 1950). Taking note of this growing support, a Legion official noted that while "we are definitely losing [this fight] in the press," "we may win [it] in Congress" (Cejnar to Saidt 1950).

On the other side of the fence, the CCHR was reluctantly reaching the same conclusion. Informed of the Legion's massive counter-campaign, McCormick wrote an alarmed letter to 
Coates in January where he expressed his fear that "if we wait too long before we do our work, we will be completely stopped" (McCormick to Coates 1950). The next month, they both recognized that the Legion had been "giving us a very bad time," and that the CCHR needed to react immediately if it were to prevent Legionnaires from "trying to rope and hogtie all the Congressmen in advance." Nevertheless, CCHR officials refused to use similar tactics. They genuinely believed that the Hoover Report was above politics and that its defense should therefore be grounded mainly in the austere exposition of facts, as opposed to what they saw as the Legion's "strictly emotional appeal" (McCormick to Pollock 1950; Coates to Stuart 1950). CCHR speakers, for instance, were urged to "[a]void rip-snorting words such as 'slash,' 'abolish,' 'taxeater,' 'bureaucrat,' 'living at the public teat,"” and to strive "above all, [for] exactitude" ("Do's and Don'ts" n.d.). "[W]e do not intend to engage in any shirt-waving," McCormick made clear in a private letter, "[t]hat's not our specialty" (McCormick to Lucas 1952). Yet this less aggressive approach failed to break the deadlock in Congress. As McCormick acknowledged in a letter to Hoover, by the end of 1950 "[v]irtually nothing" had been done regarding the reform of veterans' affairs, the creation of the United Medical Administration remained "a major task," and "[n]othing was accomplished" on the bill to reform civil service (McCormick to Hoover, November 1950).

The next year did little to improve the situation. Johnson hoped that the election of a new Legion National Commander in October 1950_Erle Cocke, Jr., of Georgia—would "brush aside a great many of the irritations of the past" (Johnson to Cocke 1950). Yet negotiations soon broke down again with the acknowledgment that the positions of both groups remained "irreconcilable" and the "lines of battle...clearly drawn" (Memorandum to Cocke n.d.). Cocke was determined to follow in the footsteps of his predecessor. In the light of the public's hostile reaction to Operation Survival, he decided to avoid publicizing his group's opposition to the Hoover Report. Calculating that this would only add grist to the CCHR's mill, he chose to focus instead on what the Legion did best: lobbying legislators behind the scenes by flooding their offices with letters from constituents back home (Oakey 1951). As one Legion official put it, "it is pretty much our policy this year to oppose these things in the Committees of Congress rather than in the press of the nation" (Oakey to Irish 1951). In doing so, the Legion continued to rely on Rankin to bottle up the bills to reform the VA and create a Veterans' Insurance Corporation. He refused to invite the CCHR to testify at hearings, admitting only representatives of the Legion, VFW, DAV, and AMVETS, as well as officials of government agencies and members of Congress - a decision Johnson described as "exactly as though a court of law were to announce that it would hear only witnesses for the defense [sic]" ("Attention, Veterans" 1951; Rankin to Biddle 1951).

Faced with such a seemingly insurmountable wall, CCHR officials tried a different tack. In August 1951, they formed the Independent Veterans' Committee (IVC) with the mission to "demonstrate to Congress and the public that the established veterans' organizations are not the sole spokesman for the nation's veterans in this issue" and more specifically to free Congress "of its fear of the Legion," which they saw as their chief enemy (Coates to McCormick 1951). Its "paramount objective" was to "get some action on [the] reform of the VA" blocked by Rankin (Coates to Smith 1951). The editor of the San Francisco Chronicle and decorated veteran of the Pacific Paul Smith was named chairman, and the list of founding members included such prestigious names as Hollywood actor Douglas Fairbanks, the son of the publishing magnate Randolph A. Hearst, Army Generals Lucius Clay and A. C. Wedemeyer, the President of the University of Pennsylvania Harold E. Stassen, and T. Coleman Andrews, accountant and future presidential candidate of the States' Rights Party in 1956 ("Founding Members" 1951; "Veterans to Spur," New York Times 1951). What the names did not reveal was that the IVC was merely a 
figurehead for the CCHR: its members were all handpicked by Coates and McCormick and were there only to give public speeches while the CCHR handled all the staff work (Coates to McCormick 1951). In short, the IVC was an example of what would later be known as an "astroturf" group: a staged grassroots campaign which, as the Legion realized, had "no other purpose than to lend the name "veterans' to the support of the Hoover proposals" ("Group Seeks to Destroy," American Legion Magazine 1952).

Even with the creation of this new group, the CCHR made little headway in 1951. Its only minor victory was when the Senate voted the bill to reform civil service one day before adjourning (Digest of Minutes 1951: 41). The bill to create a UMA was replaced by one to create a Department of Health, but nobody was willing to seriously consider such sweeping reforms in the emergency situation created by the Korean War. By the end of the year, the CCHR estimated that slightly more than half of all the Commission's recommendations had been implemented, but that 5.5 billion dollars could still be saved with those that remained ("55\% Streamlined," The Washington Post 1952; House Committee on Veterans' Affairs 1952: 2214). It decided to focus for the next year on six bills "of primary importance," those "in areas where the greatest savings can be made, where waste, overlapping and duplication are most prevalent and where the largest government agencies and private pressure groups are in a position to offer the strongest resistance to change and improvement." Three of them were related to veterans' affairs: Federal Personnel Management, the Department of Health, and the reorganization of the VA ("Here Are the Major Targets" n.d.). Though the CCHR had initially planned to disband in January 1952, it decided to continue operating until May in order to make a final push for these bills, after which it would suspend its activities to avoid being forced to take sides in the upcoming presidential campaign (Coates to Smith 1952; Digest of Minutes 1951: 16).

Unbeknownst to the CCHR, the Legion was already charting its own final offensive. Aware that this was the last session of Congress before its foe would disband, the National Commander decided to embark on one last push in order "to get these fellows on the defensive" and not "quit the job until the thing was definitely at rest" (Digest of Minutes May 1952: 39-40). Illustrating the progress that the Legion knew it had achieved since Operation Survival in 1950, the new campaign was called "Operation Victory." The methods, however, were the same: Legion lobbyist John Thomas Taylor asked rank-and-file Legionnaires to "literally flood" their Congressional delegation with letters and petitions, while national officials would meet with the latter in person at several different events in the spring ("OPERATION VICTORY" 1951). Since the press and to a lesser extent the public remained hostile, Taylor continued to direct efforts inward rather than outward, seeking to mobilize his members rather than to sway collective opinion. The Legion thus returned to the same hyperbolic rhetoric it had employed two years earlier. The March 1952 issue of its Legislative Bulletin, for instance, called the bill to create a Department of Health a "diabolic scheme" part of the larger "octopus-like maneuvering" by the CCHR "to strangle the VA, destroy Veterans' Preference, and place all veterans' benefits in jeopardy..." (National Legislative Commission 1952). "This is the most crucial point in our history," wrote the head of the Kansas Department to all Post Commanders in his state, "If we fail in this fight, we have little or no future...Gentlemen, this is it. Either we win this fight, or we lose every benefit we have secured for our Veterans and the American Legion is a doomed organization" (Smith to All Post Commanders 1952).

Confident that he had the upper hand, Taylor calculated that it was time to score a clearcut victory. He took advantage of the professional ties forged with Rankin over more than two decades of close collaboration to convince him to finally allow hearings on the bills to reorganize 
the VA and create a Veterans' Insurance Corporation, so that the Legion would be able to defeat them soundly (Digest of Minutes May 1952: 43-44). When the hearings took place in the spring, it was clear that his strategy had worked, for the CCHR faced a skeptical committee. Openly hostile, Rankin argued that the reorganization of the VA along functional lines, with each core service under the responsibility of one deputy, would take power away from the Administrator. Such decentralization would not only "multiply the red tape" but more importantly "remove one step, the responsibility, the answerableness, to the Congress of the United States" of the Administrator-put simply, he feared it would make the VA less subservient to Congressional authority (House Committee on Veterans' Affairs 1952: 2079). In the end, his committee suspended action on both bills until the results of a management survey of the VA conducted by the consulting firm Booz Allen Hamilton was made public in September. This amounted to a defeat for the CCHR, since it meant that Congress would adjourn in July without taking any decision on the matter (Proceedings of the $34^{\text {th }}$ National Convention 1953: 336). The other two bills-on Federal Personnel Management and the Department of Health - met a similar fate. Backed once again by the DAV, the AMVETS, and the VFW, as well as by a coalition of federal employee unions, the Legion repeated the same familiar arguments against the proposed reform of civil service (House Committee on Post Office and Civil Service 1952: 219-236). Taylor was confident that the House Committee on Post Office and Civil Service felt "well disposed toward us at the moment," and indeed the bill was not reported out before the end of the session (Digest of Minutes May 1952: 43). Likewise, the bill to create a Department of Health never got out of committee (Proceedings of the $34^{\text {th }}$ National Convention 1953: 179-180).

With the suspension of the CCHR's activities and the adjournment of Congress in July 1952, the Legion's two-year campaign came to a successful conclusion. As the IVC itself recognized, "in nearly three years little real progress toward better organization and management had been made" ("Action Sheet" n.d.). The Legion could boast that "[n] ot a single one of the bills advocated by the CCHR and opposed by The American Legion was enacted into law" (Digest of Minutes August 1952: 5). In recognition of Taylor's work, the group passed a resolution praising his "magnificent accomplishment of Operation Victory". For a total cost of less than $\$ 30,000$, the campaign had lived up to its name (Proceedings of the $34^{\text {th }}$ National Convention 1953: 65, 420).

\section{Conclusion}

To be sure, neither Taylor nor the Legion or even the veterans' movement as a whole could claim sole responsibility for this achievement. As this article has demonstrated, they benefited from the fact that the lobbyists of the First Hoover Commission were so convinced of the superiority of their own ideas that they refused to engage in the same aggressive tactics as their opponents, even after realizing that they were losing ground. Hoover's campaign also suffered from a problem familiar to all advocates of reform: while support for the general idea of government reorganization was strong, it tended to dissolve once the discussion shifted to more specific issues. Several key political figures, such as the Director of the VA and the Chairman of the House Committee on Veterans' Affairs, adamantly resisted what they saw as an attack on their own turf and therefore became key allies of the veterans' movement. Finally, the onset of the Korean War in June 1950 added yet another obstacle on the road to Hoover's goals, for the war effort made any wide-ranging government overhaul unlikely. It is within this broader favorable context that we must understand the decisive role played by the Legion and the veterans' movement. 
What makes this controversy interesting, then, is less what it said about the strength of the Legion or any other group than what it revealed about the dynamics of veterans' politics. Contrary to the conventional wisdom about the triumphal return of the "Greatest Generation," this episode demonstrates that veterans' affairs in the post-World War II period remained as fiercely contested as ever. Far from being limited to the low-profile machinations of a handful of bureaucrats, lawmakers, and lobbyists operating behind closed doors in Washington, D.C.- as implied by the prevailing concepts of a "subgovernment" or "iron triangle"-veterans' politics drew the attention of a diverse cast of actors ranging from ordinary former soldiers to doctors to the national press and the President. The stakes of the conflict were nothing less than the future of the U.S. welfare state itself, of which veterans' programs represented a central pillar in the postwar period. It is therefore hardly a surprise that the issue generated a high level of enthusiasm among rank-and-file Legionnaires, whose interaction with national leaders was key to the success of their countercampaign. In the end, it is this interaction that makes it possible to see veterans' advocacy as a social movement.

Operation Victory was not the last time that Americans would debate the fate of veterans' welfare state, for new threats were already emerging even as this campaign was winding down. The onset of the Korean War forced the country to confront the thorny issue of what benefits to grant a new generation of veterans. In 1953, Eisenhower created a Second Hoover Commission to take up the torch of the First. Two years later, he appointed his own presidential Commission on Veterans' Pensions with the goal of reviewing the entire structure of veterans' benefits. In short, former soldiers would continue to defend their benefits against liberals and conservatives alike throughout the decade. The clash between the Legion and the First Hoover Commission had been but a skirmish in the ongoing battle over veterans' welfare state-albeit one that provides us with key insights into how this policy area operated. 


\section{Archival Sources}

$\underline{\text { Wisconsin Historical Society, Madison, Wisconsin }}$

(1950) "Legion Declares Private War.” The Badger Legionnaire, February.

(1950) "Time for Action.” The Badger Legionnaire, February.

American Legion Archives, Indianapolis, Indiana

(1950) “American Legion Mobilizes for Offensive against 'Economy' Sell-Out of Veterans by Hoover Report.” American Legion Magazine, February.

(1950) "Hoover Commission Report, Subject: Campaign Being Carried on by American Legion

Departments as Requested in National Adjutant's Letter of March 3, 1950." United States, Reorganization (inc. Hoover Plan), A-Z.

(1950) "House Leader Says Split of VA Will Add to Costs." American Legion Magazine, March. (1950) "McCurdy Denounces Economy Movement as a Blow at Disabled War Veterans." American Legion Magazine, January.

(1950) "Pass the Ammunition!! What Every Post Should Do." American Legion Magazine, February.

(1951) Digest of Minutes, National Executive Committee Meeting, Indianapolis, Indiana, November 18, 19 and 20.

(1952) "Group Seeks to Destroy U.S. Vet's Program in Four Months." American Legion Magazine, February.

(1952) Digest of Minutes, National Executive Committee Meeting, Indianapolis, Indiana, May 5, 6 and 7.

(1952) Digest of Minutes, National Executive Committee Meetings, New York City, N.Y., August 24 and 28.

(1952) Proceedings of the $33^{\text {rd }}$ National Convention of the American Legion. Washington, D.C.:

U.S. Government Printing Office.

(1953) Proceedings of the $34^{\text {th }}$ National Convention of the American Legion. Washington, D.C.:

U.S. Government Printing Office, 1953.

(n.d.) "Play Fair, Legion." Washington (D.C.) Times-Herald, (ca. February 5, 1950). United States, Reorganization (inc. Hoover Plan), Comments.

(n.d.) "What Would Happen to the Veteran if these Proposals Became Law," United States, Reorganization (inc. Hoover Plan), A-Z.

"National Rehabilitation Conference, The American Legion: February 6-7-8-9, 1950, Washington, D.C.: Change in Date," December 15, 1949. United States, Reorganization (inc. Hoover Plan), A-Z.

“Suggested Agenda, January 7 and 8, 1950." United States, Reorganization (inc. Hoover Plan), AZ.

Brown, Perry. (1949) “The Growing Attack on Veterans' Benefits.” American Legion Magazine, July.

CCHR. (n.d.) "Here Are the Major Targets...The Big Six," (ca. December 1951). United States, Reorganization (inc. Hoover Plan), A-Z.

Cejnar to Saidt, March 17, 1950. United States, Reorganization (inc. Hoover Plan), A-Z. 
Craig, George N. (1949) "(Call to special conference of Department Commanders in U.S. only)," December 1. United States, Reorganization (inc. Hoover Plan), A-Z.

Department Headquarters, "Release upon Receipt," received January 20, 1950. United States, Reorganization (inc. Hoover Plan), A-Z.

Deutschle to Craig, January 23, 1950. United States, Reorganization (inc. Hoover Plan), Comments, Departments AL-WY.

Fuecker to Dudley, February 9, 1950. United States, Reorganization (inc. Hoover Plan), Comments, Departments AL-WY.

Johnson to Cocke, November 14, 1950. United States, Reorganization (inc. Hoover Plan), A-Z.

Letter from George N. Craig, January 1, 1950. United States, Reorganization (inc. Hoover Plan), A-Z.

McGinnis, Edward F. (n.d.) "Operation Survival," (ca. January 8, 1950). United States, Reorganization (inc. Hoover Plan), A-Z.

Memorandum to Erle Cocke, Jr., from Leonce Legendre, T. O. Kraabel, et al., n.d. (ca. February 1951). United States, Reorganization (inc. Hoover Plan), A-Z.

Mundt to Craig, February 27, 1950. United States, Reorganization (inc. Hoover Plan), A-Z.

National Legislative Commission. (1950) Legislative Bulletin, no. 5. February 7, 1950. United States, Reorganization (inc. Hoover Plan), A-Z.

National Legislative Commission. (1952) Legislative Bulletin, Special Bulletin No. 4, March 1. United States, Reorganization (inc. Hoover Plan), Operation Victory.

National Public Relations Division (n.d.) "Suggested 15-Minute Talk for American Legion Speakers: The American Legion and the Hoover Report" (ca. January 1950). United States, Reorganization (inc. Hoover Plan), A-Z.

Oakey to Irish, May 14, 1951. United States, Reorganization (inc. Hoover Plan), United States, Reorganization (inc. Hoover Plan), A-Z.

Oakey to Kraabel, January 27, 1950. United States, Reorganization (inc. Hoover Plan), A-Z.

Oakey, Jack. (1951) "Memorandum to Henry H. Dudley, William E. Sayer," January 4. United States, Reorganization (inc. Hoover Plan), A-Z.

Operations-Chief of Staff to the National Commander, "OPERATION VICTORY," December 10, 1951. United States, Reorganization (inc. Hoover Plan), Operation Victory.

Smith to all Post Commanders, received February 20, 1952. United States, Reorganization (inc. Hoover Plan), Operation Victory.

T. O. Kraabel to Frank J. Falcone, April 10, 1952. United States, Reorganization (inc. Hoover Plan), A-Z.

Thomas and Kerr to the President, February 7, 1950. United States, Reorganization (inc. Hoover Plan), Comments, Departments AL-WY.

Citizens Committee for Reorganization of the Executive Branch of the Government Records, Hoover Institution Archives, Stanford, California

(1951) “Attention, Veterans.” Reorganization News, October-November. Box 2, Folder 2.

(n.d.) "Action Sheet-Independent Veterans Committee for the Hoover Report" (ca. 1952). Box 73 , Folder 9.

(n.d.) "State Legion Head Scores Hoover Recommendations." Albuquerque Journal (ca. January 20, 1950). Box 73, Folder 2. 
(1951) "Founding Members, Independent Veterans Committee for the Hoover Report," September 6. Box 73, Folder 9.

Charles B. Coates to John Stuart, February 1, 1950. Box 73, Folder 2.

Coates to Ely, January 13, 1950. Box 73, Folder 3.

Coates to Johnson, February 27, 1952. Box 72, Folder 1.

Coates to McCormick, June 21, 1951. Box 73, Folder 9.

Coates to Smith, June 21, 1951. Box 73, Folder 9.

Coates to Smith, March 25, 1952. Box 73, Folder 9.

McAtee to Coates, "Memo re: Veterans," February 15, 1950. Box 73, Folder 2.

McCormick to Coates, Memorandum: Veterans, January 20, 1950. Box 73, Folder 2.

McCormick to Lucas, April 4, 1952. Box 72, Folder 1.

McCormick to Pollock, February 9, 1950. Box 73, Folder 2.

Rankin to Biddle, June 19, 1951. Box 2, Folder 2.

George Sokolsky Papers, Hoover Institution Archives, Stanford, California

Sokolsky, George. (1949) “These Days.” Washington Times-Herald, October 23. Box 279, Folder 5.

$\underline{\text { Records of the First Hoover Commission, Herbert Hoover Presidential Library, West Branch, Iowa }}$

(1948) "A Program to Promote the Recommendations of The Commission on Organization of the Executive Branch of the Government: The State Program Phase," December 31. Box 32, Folder: Charles B. Coates, 1948-49.

CCHR. (n.d.) "Impact! Of the Cracker Barrel Caravan" (ca. July 1951). Box 32, Folder: Charles B. Coates, 1950.

Coates, Charles B. (1949) "Memorandum for the Honorable Herbert Hoover." January 5. Box 32, Folder: Charles B. Coates, 1948-49.

McCormick to Hoover, November 20, 1950. Box 35, Folder: Robert L. L. McCormick, JuneDecember, 1950.

McCormick to Hoover, October 13, 1950. Box 35, Folder: Robert L. L. McCormick, JuneDecember, 1950.

McCormick to Weymouth, September 29, 1950. Box 35, Folder: Robert L. L. McCormick, JuneDecember, 1950.

White House Central Files, Official File, Truman Papers, Truman Library, Independence, Missouri

(n.d.) "National Reorganization Conference Agenda" (ca. December 1949). OF 285 E Citizens Committee for Reorganization of the Executive Branch of the Government.

CCHR. (n.d.) "'Do's and Don'ts,' on Preparing Material about the Hoover Report” (ca. November 28, 1949). OF 285 E Citizens Committee for Reorganization of the Executive Branch of the Government

Clark, G. L. (1950) Memo to the File Room, September 21. OF 285 E (1950-1953).

\section{References}


(1941) Annual Report of the Administrator of Veterans' Affairs, 1940. Washington, D.C.: U.S. Government Printing Office.

(1944) "Disabled Veterans Will Receive Care: General Hines Says Many Have Been Placed on Pensions." New York Times, June 22.

(1944) "Plans Are Already Under Way to Pay World War II Pensions." The Christian Science Monitor, January 13.

(1949) "Summary of Reports of the Hoover Commission." Public Administration Review 9 (April): 73-99

(1949) "Veterans' Preference." The Washington Post, December 21.

(1950) "4 Billions Not Saved." Chicago Tribune, April 14.

(1950) "American Legion Cartoon Hit by Hoover Group." New York Herald Tribune, February 12.

(1950) “American Veterans Hail Hoover's G.I. Plan; Denounce Legion on Stand Over Hospitals.”

New York Times, February 27.

(1950) "Battle Developing Over Veteran Unit: 4 Ex-Servicemen's Groups Fight Hoover Reforms,

as Citizen Committee Advocates Them.” New York Times, January 20.

(1950) "Congress and Legion." The Washington Post, February 4.

(1950) "Legion Blast." The Washington Post, February 8.

(1950) "Pressure, With Brass Knucks." Newsday, February 14.

(1950) "Truman, Legion Head Talk: President Is Told Group Opposes Veteran Agency Reforms."

New York Times, January 26.

(1950) "Veterans' Report." New York Times, February 15.

(1950) Annual Report: Administrator of Veterans Affairs, 1949. Washington, D.C.: U.S.

Government Printing Office.

(1951) "Veterans to Spur U.S. Streamlining: Heads New Committee." New York Times, August 19.

(1952) "55\% Streamlined." The Washington Post, February 18.

(1952) "Exit Mr. Rankin." The Washington Post, August 28.

Adler, Jessica L. (2017) Burdens of War: Creating the United States Veterans Health System. Baltimore: Johns Hopkins University Press.

Aikin, Charles, and Louis W. Koenig. (1949) "I. Introduction." The American Political Science Review 43: 933-40.

Alcalde, Ángel, and Xosé M. Núñez Seixas, eds. (2018) War Veterans and the World after 1945:

Cold War Politics, Decolonization, Memory. New York: Routledge, Taylor \& Francis Group.

Arnold, Peri E. (1976) "The First Hoover Commission and the Managerial Presidency." The Journal of Politics 38 (1): 46-70.

Berry, Jeffrey M., and Clyde Wilcox. (2018) The Interest Group Society. 6th ed. New York: Routledge.

Boulton, Mark. (2014) Failing Our Veterans: The G.I. Bill and the Vietnam Generation. New York: New York University Press.

Bradley, Omar Nelson, and Clay Blair. (1983) A General's Life: An Autobiography. New York: Simon and Schuster.

Brokaw, Tom. (1998) The Greatest Generation. New York: Random House.

Burns, James MacGregor. (1949) “Our Super-Government -- Can We Control It?” New York Times, April 24. 
Cahn, Frances T. (1949) Federal Employees in War and Peace: Selection, Placement and Removal. Washington: Brookings Institution.

Carnes, Mark. (1989) Secret Ritual and Manhood in Victorian America. New Haven: Yale University Press.

Carter, Susan B. et al., eds. (2006) Historical Statistics of the United States: Earliest Times to the Present, Millennial ed., volume 5. New York: Cambridge University Press.

Clawson, Mary Ann. (1989) Constructing Brotherhood: Class, Gender, and Fraternalism. Princeton: Princeton University Press.

Crotty, Martin, and Mark Edele. (2013) "Total War and Entitlement: Towards a Global History of Veteran Privilege.” Australian Journal of Politics \& History 59: 15-32.

Dandeker, Christopher, Simon Wessely, Amy Iversen, and John Ross. (2006) "What's in a Name? Defining and Caring for 'Veterans': The United Kingdom in International Perspective." Armed Forces \& Society 32: 161-77.

Danilova, Natalia. (2010) "The Development of an Exclusive Veterans' Policy: The Case of Russia." Armed Forces \& Society 36: 890-916.

Dickson, Paul, and Thomas B. Allen. (2004) The Bonus Army: An American Epic. New York: Walker \& Co.

Edele, Mark. (2008) Soviet Veterans of the Second World War: A Popular Movement in an Authoritarian Society, 1941-1991. Oxford: Oxford University Press.

Eichenberg, Julia, and John Paul Newman, eds. (2013) The Great War and Veterans' Internationalism. New York: Palgrave Macmillan.

Eisenach, Eldon J. (1994) The Lost Promise of Progressivism. Lawrence, Kan.: University Press of Kansas.

England, Robert. (1950) Twenty Million World War Veterans. Toronto, New York: Oxford University Press.

Frydl, Kathleen. (2009) The GI Bill. Cambridge: Cambridge University Press.

Gallup Organization (1950) Gallup Poll (AIPO), February 1950. "The Hoover Commission on Reorganization of Government claims that many millions of dollars can be saved by splitting up major functions (jobs) of the Veterans Administration among other government agencies in Washington. Veterans organizations oppose this saying that it would be neither efficient nor economical. What do you think-should Congress follow the views of the Hoover Commission or of the veterans organizations?" USGALLUP.50-453.QK08B. Cornell University, Ithaca, NY: Roper Center for Public Opinion Research, iPOLL. Accessed May 8, 2017.

Gallup, George. (1950) "Voters Overwhelmingly Back Hoover Commission Report." The Washington Post, March 8.

Gordon, Linda. (1992) "Social Insurance and Public Assistance: The Influence of Gender in Welfare Thought in the United States, 1890-1935." The American Historical Review 97: 1954.

Gray, Justin, and Victor H. Bernstein. (1948) The Inside Story of the Legion. New York: Boni \& Gaer.

Grisinger, Joanna. (2012) The Unwieldy American State: Administrative Politics since the New Deal. New York: Cambridge University Press.

Heclo, Hugh. (1978) "Issue Networks and the Policy Establishment," in Anthony King (ed.) The New American Political System, Washington, D.C.: American Enterprise Institute for Public Policy Research: 87-124. 
Jensen, Laura. (2003) Patriots, Settlers, and the Origins of American Social Policy. Cambridge: Cambridge University Press.

Kammerer, Gladys M. (1948) "The Veterans Administration in Transition.” Public Administration Review 8 (Spring): 103-9.

Katz, Michael B. (1989) The Undeserving Poor: America's Enduring Confrontation with Poverty. New York: Pantheon Books.

Keene, Jennifer D. (2001) Doughboys, the Great War, and the Remaking of America. Baltimore, Md.: Johns Hopkins University Press.

Kinder, John M. (2015) Paying with Their Bodies: American War and the Problem of the Disabled Veteran. Chicago: University of Chicago Press.

Knowless, Clayton. (1949) "Hoover Warns U.S. Must Halt Waste to Retain Liberty.” New York Times, December 13.

Linker, Beth. (2011) War's Waste: Rehabilitation in World War I America. Chicago: University of Chicago Press.

Littlewood, Thomas B. (2004) Soldiers Back Home: The American Legion in Illinois, 1919-1939. Carbondale: Southern Illinois University Press.

Marten, James Alan. (2011) Sing Not War: The Lives of Union \& Confederate Veterans in Gilded Age America. Chapel Hill: University of North Carolina Press.

Mason, Jr., Herbert Molloy. (1999) VFW: Our First Century, 1899-1999. Lenexa, KS: Addax.

McKean, Dayton David. (1949) Party and Pressure Politics. Boston: Houghton Mifflin Co.

Miller, Lois Mattox, and James Monahan. (1947) "Veterans' Medicine: Second to None!" Reader's Digest, September 1947.

Moe, Ronald C. (1982) The Hoover Commissions Revisited. Boulder, Col.: Westview Press.

Moore, Colin D. (2015) "Innovation without Reputation: How Bureaucrats Saved the Veterans' Health Care System." Perspectives on Politics 13: 327-44.

Nicosia, Gerald. (2001) Home to War: A History of the Vietnam Veterans' Movement. New York: Crown Publishers.

Ortiz, Stephen R. (2010) Beyond the Bonus March and GI Bill: How Veteran Politics Shaped the New Deal Era. New York: New York University Press.

— Modern United States. Gainesville: University Press of Florida.

Pash, Melinda L. (2012) In the Shadow of the Greatest Generation: The Americans Who Fought the Korean War. New York: New York University Press.

Pemberton, William E. (1979) Bureaucratic Politics: Executive Reorganization during the Truman Administration. Columbia: University of Missouri Press.

Pemberton, William E. (1986) "Struggle for the New Deal: Truman and the Hoover Commission." Presidential Studies Quarterly 16: 511-27.

Pencak, William. (1989) For God \& Country: The American Legion, 1919-1941. Boston: Northeastern University Press.

Poen, Monte M. (1979) Harry S. Truman versus the Medical Lobby: The Genesis of Medicare. Columbia: University of Missouri Press.

Polenberg, Richard. (1966) Reorganizing Roosevelt's Government, 1936-1939: The Controversy over Executive Reorganization. Cambridge, Mass.: Harvard Univ. Press.

Prost, Antoine. (1992) In the Wake of War: Les Anciens Combattants and French Society. Oxford, UK: Berg. 
Public Affairs Institute. (1949) The Hoover Report: Half a Loaf. Occasional Paper Series 3. Washington, D.C.

Rennie, Ysabel and Robert Rennie. (1950) "Political Economy: Veterans as a Special Interest." The Washington Post, January 17.

Resch, John Phillips. (1999) Suffering Soldiers: Revolutionary War Veterans, Moral Sentiment, and Political Culture in the Early Republic. Amherst: University of Massachusetts Press.

Roher, Miriam. (1946) "Veterans and the Civil Service." The American Mercury, December 1946. Roper, Elmo. (1952) "Roper Study Indicates Role of Groups in Swaying Voters." New York Herald Tribune, May 19.

Ross, Davis R. B. (1969) Preparing for Ulysses: Politics and Veterans During World War II. New York: Columbia University Press.

Saxe, Robert Francis. (2007) Settling Down: World War II Veterans' Challenge to the Postwar Consensus. New York: Palgrave Macmillan.

Scott, Wilbur J. (2004) Vietnam Veterans Since the War: The Politics of PTSD, Agent Orange, and the National Memorial. Norman, OK: University of Oklahoma Press.

Shaffer, Donald Robert. (2004) After the Glory: The Struggles of Black Civil War Veterans. Lawrence, Kan.: University Press of Kansas.

Skocpol, Theda. (1992) Protecting Soldiers and Mothers: The Political Origins of Social Policy in the United States. Cambridge, Mass.: Belknap Press of Harvard University Press.

Stevens, Rosemary A. (2012) "The Invention, Stumbling, and Reinvention of the Modern U.S. Veterans Health Care System, 1918-1924," in Stephen R. Ortiz (ed.) Veterans' Policies, Veterans' Politics: New Perspectives on Veterans in the Modern United States. Gainesville, Fl.: University Press of Florida: 38-62.

Strolovitch, Dara Z., and Daniel J. Tichenor. (2016) "Interest Groups and American Political Development," in Richard M. Valelly, Suzanne Mettler, and Robert C. Lieberman (eds.) The Oxford Handbook of American Political Development. Oxford: Oxford University Press: 53562.

Teigen, Jeremy M. (2018) Why Veterans Run: Military Service in American Presidential Elections, 1789-2016. Philadelphia: Temple University Press.

Thurber, James A. (1991) "Dynamics of Policy Subsystems in American Politics," in Allan J. Cigler and Burdett A. Loomis (eds.) Interest Group Politics, 3rd ed. Washington, D.C.: CQ Press: $319-43$.

Tilly, Charles, and Sidney Tarrow. (2015) Contentious Politics. 2nd ed. New York: Oxford University Press.

Truman, Harry S. (1950) "Annual Budget Message to the Congress: Fiscal Year 1951 - January 9, 1950." Public Papers of the Presidents of the United States 1950.

U.S Congress, House, Committee on Expenditures in the Executive Departments. (1949a) First Report of the Commission on Organization of the Executive Branch of Government Washington, D.C.: U.S. Government Printing Office.

- (1949b) Report of Commission on Organization of Executive Branch of the Government on Federal Medical Activities. Washington, D.C.: U.S. Government Printing Office.

—. (1950) United Medical Administration, Hearing, March 29, June 13-14, 22, July 12, 1950. Washington, D.C.: U.S. Government Printing Office.

U.S Congress, House, Committee on Post Office and Civil Service. (1952) Recruitment Procedures in the Federal Government, Hearing, March 25-26, April 1, 3, 8, 24, 29, May 13, 15, 1952. Washington D.C.: U.S Government Printing Office. 
U.S Congress, House, Committee on Veterans' Affairs. (1949a) Comments of the Veterans Administration on the Recommendations of the Commission on Organization of the Executive Branch of Government as Applied to the Activities of the Veterans Administration. Washington, D.C.: U.S. Government Printing Office.

- (1949b) Report of Commission on Organization of Executive Branch of the Government on Veterans' Affairs. Washington, D.C.: U.S. Government Printing Office.

- (1949c) Report of the Hoover Commission Committee on Veterans' Affairs (Commission Task Force) to the Commission on Organization of the Executive Branch of the Government. Washington, D.C.: U.S. Government Printing Office.

- (1952) Recommendations of Commission on Organization of the Executive Branch of the Government (Hoover Commission) Providing for Reorganization of the Veterans' Administration and Creating a Veterans' Insurance Corporation, Hearing, May 27-28, June 36, 10-12, 1952. Washington, D.C.: U.S. Government Printing Office.

U.S Congress, Senate, Committee on Expenditures in the Executive Departments. (1949) Progress on Hoover Commission Recommendations. Washington, D.C.: U.S. Government Printing Office.

U.S Congress, Senate, Committee on Labor and Public Welfare, Subcommittee on Health. (1950) United Medical and Hospital Administration Act, Hearing, July 10-12, 1950. Washington, D.C.: U.S. Government Printing Office.

U.S. Congress, House, Committee on Government Operations. (1963) Summary of the Objectives, Operations, and Results of the Commissions on Organization of the Executive Branch of the Government. Washington, D.C.: U.S. Government Printing Office.

Walch, Timothy, and Dwight M. Miller, eds. (1992) Herbert Hoover and Harry S. Truman: A Documentary History. Worland, Wyo: High Plains Pub. Co.

Warner, James E. (1950) “Hoover Group Asks Apology from Legion: Citizens' Committee Terms Cartoon in Drive Against V.A. Reform 'Scurrilous," New York Herald Tribune, February 12. Weissert, William G., and Carol S. Weissert. (2012) Governing Health: The Politics of Health Policy. 4th ed. Baltimore: Johns Hopkins University Press.

Whalen, Robert Weldon. (1984) Bitter Wounds: German Victims of the Great War, 1914-1939. Ithaca, N.Y: Cornell University Press.

White, John. (1952) "Did You Happen to See: Robert L. L. McCormick." Times Herald, June 22. Zeller, Belle. (1937) Pressure Politics in New York: A Study of Group Representation before the Legislature. New York: Prentice-Hall. 